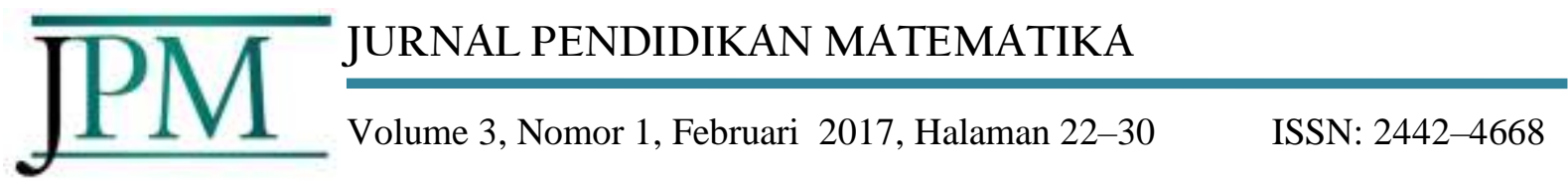

\title{
PENGEMBANGAN KOMIK MATEMATIKA BERBASIS RME (REALISTIC MATHEMATICS EDUCATION) UNTUK MENINGKATKAN KEMAMPUAN PEMECAHAN MASALAH KELILING DAN LUAS SEGITIGA SISWA SMP KELAS VII
}

\author{
Evita Dwi Ramadhani \\ (Mahasiswa Program Studi Pendidikan Matematika FKIP Universitas Islam Malang) \\ Email: evitadwi74@yahoo.com
}

\begin{abstract}
Abstrak
Pengembangan ini bertujuan untuk menghasilkan komik matematika berbasis RME (Realistic Mathematics Education) untuk meningkatkan kemampuan pemecahan keliling dan luas segitiga siswa SMP kelas VII. Pengembangan komik matematika berbasis RME ini menggunakan model pengembangan 4-D (four-D) yang terdiri dari empat tahap, yaitu: define, design, develop, dan disseminate. Komik matematika berbasis RME divalidasi oleh tiga validator yang meliputi satu ahli media, satu ahli materi, dan satu praktisi guru matematika SMP. Setelah komik matematika berbasis RME dinyatakan valid, kemudian diujicobakan kepada sembilan siswa kelas VII SMP Wahid Hasyim Malang. Berdasarkan hasil analisis data, secara keseluruhan komik matematika berbasis RME yang dikembangkan dinyatakan valid dengan rata-rata nilai dari semua validator adalah 3,2. Sedangkan pada uji coba user, komik matematika berbasis RME dinyatakan valid dengan rata-rata nilai kevalidan 3,44. Sehingga dapat disimpulkan bahwa komik matematika berbasis RME dinyatakan valid untuk digunakan sebagai media pembelajaran materi keliling dan luas segitiga.
\end{abstract}

Kata Kunci: Pengembangan, komik matematika, RME, keliling dan luas segitiga

\section{PENDAHULUAN}

Pendidikan memiliki banyak unsur di dalamnya. Salah satu dari unsur pendidikan tersebut adalah adanya proses pembelajaran. Guru harus melaksanakan pembelajaran yang efektif agar siswa mudah dalam memahami materi yang disampaikan. Pembelajaran efektif yang dimaksud adalah pembelajaran yang menvisualisasikan objek atau kejadian dalam bahan pengajaran secara realistik menyerupai keadaan yang sebenarnya (Sudjana \& Riva'i, 2015:9). Dalam pembelajaran matematika pendekatan ini disebut dengan pendekatan realistik, dengan pendekatan ini siswa akan mampu memecahkan masalah dalam pembelajaran matematika yang sering ditemukan dalam kehidupan sehari-hari.

Salah satu solusi yang disarankan untuk mempermudah kemampuan abstraksi siswa adalah dengan menggunakan alat bantu berupa media pembelajaran. Penggunaan media yang tepat merupakan sarana untuk mengefektifkan proses penyampaian materi pelajaran kepada siswa. Menurut Hamalik (dalam Arsyad, 2011:19) pemakaian media pembelajaran dalam proses pembelajaran dapat membangkitkan keinginan dan minat yang baru, membangkitkan motivasi dan rangsangan kegiatan belajar, dan bahkan membawa pengaruh-pengaruh psikologis terhadap siswa.

Kurangnya penggunaan media untuk materi keliling dan luas segitiga dibuktikan dari hasil angket kebutuhan yang diberikan kepada 30 siswa SMP kelas VII semester genap tahun ajaran 2015/2016. Hasil angket menunjukkan $88 \%$ siswa memerlukan media pembelajaran untuk materi keliling dan luas segitiga. Atas pertimbangan tersebut, maka dibutuhkan pengembangan media pembelajaran matematika untuk mengurangi pemikiran negatif siswa terhadap pelajaran 
matematika serta untuk membangkitkan minat siswa dalam menyelesaikan permasalahan matematika dalam kehidupan sehari-hari yang berhubungan dengan keliling dan luas segitiga.

Komik matematika yang digunakan dalam penelitian ini merupakan suatu media untuk pembelajaran yang bentuknya dibuat seperti komik pada umumnya, yang bisa menarik minat siswa dalam belajar matematika. Komik dikemas dalam bentuk media cetak yang berukuran A5 (14,8 cm x $21 \mathrm{~cm}$ ), bagian dalam komik dicetak menggunakan kertas HVS 100 gram sedangkan untuk bagian cover dicetak menggunakan kertas ivory 260 yang dijilid dalam bentuk soft cover tanpa laminasi. Pada komik matematika ini berisi persoalan yang berkaitan dengan materi keliling dan luas segitiga.

Tidak hanya media yang menjadi masalah penting dalam pembelajaran, akan tetapi pendekatan juga merupakan suatu masalah penting dalam mencapai tujuan pembelajaran. Maka dari itu salah satu cara yang cukup relevan untuk memecahkan permasalahan tersebut adalah pembelajaran dengan menggunakan komik yang berbasis Realistic Mathematics Education (RME).

Tujuan pengembangan ini adalah menghasilkan komik matematika berbasis RME (Realistic Mathematics Education) materi keliling dan luas segitiga siswa SMP. Dengan menggunakan pendekatan RME, komik akan meningkatkan kemampuan pemecahan masalah matematika, karena pemecahan soal yang ada dalam komik disesuaikan dengan pendekatan RME, sehingga pemecahan masalah matematika akan terurut dan bermakna bagi siswa.

\section{KAJIAN TEORI}

\section{Komik Matematika}

Menurut Sudjana \& Rivai (2015:64) komik didefinisikan sebagai suatu bentuk kartun yang mengungkapkan karakter dan memerankan suatu cerita dalam urutan yang erat dihubungkan dengan gambar dan dirancang untuk memberikan hiburan untuk para pembaca. Pemakaian yang luas dengan ilustrasi yang berwarna, alur cerita yang ringkas dengan perwatakan orangnya yang realistis menarik semua siswa dari berbagai usia. Cerita-cerita komik sangat ringkas dan menarik perhatian, komik juga dibuat lebih hidup serta diolah dengan pemakaian warna-warna utama secara bebas.

Komik matematika adalah komik yang secara implisit memuat konsep-konsep atau persoalan matematika. Proses penciptaan komik matematika pada prinsipnya tidak jauh berbeda dengan penciptaan komik-komik pada umumnya. Namun dalam komik matematika cenderung mengandung nilai plus, artinya selain memuat persoalan dan konsep matematika, juga harus mengandung "sense of humor". Adanya humor akan melahirkan kesan positif dan rasa menyenangkan siswa dalam belajar tanpa merasa adanya beban.

Komik matematika disini berisi permasalahan-permasalahan dalam kehidupan sehari-hari yang berhubungan dengan materi keliling dan luas segitiga pada kelas VII SMP, sehingga permasalahan-permasalahan matematika dalam kehidupan sehari-hari disini disajikan dalam visualisasi cerita dan dalam bentuk susunan serangkaian gambar berbingkai yang dilengkapi balonbalon dialog. Cerita dalam komik selain berisi permasalahan dalam kehidupan sehari-hari juga mengandung gaya bahasa yang mudah dipahami siswa, gambar pada komik juga disesuaikan dengan karakter siswa SMP sehingga siswa dapat merasa senang dan tertarik untuk mengikuti alur cerita serta menyelesaikan setiap permasalahan yang disajikan pada cerita.

Hasil penelitian yang mendukung antara lain dikemukakan oleh Thorndike (dalam Sudjana dan Rivai, 2015:67) menunjukkan bahwa anak yang membaca suatu buku komik setiap bulan, hampir dua kali banyaknya kata yang dapat dibaca sama dengan yang terdapat pada buku-buku bacaan yang dibaca setiap tahun terus menerus.

\section{Pendekatan RME (Realistic Mathematics Education)}

Menurut Freudenthal (dalam Wijaya, 2012:20) matematika sebaiknya tidak diberikan kepada siswa sebagai suatu produk jadi yang siap pakai, melainkan sebagai suatu bentuk kegiatan dalam mengkonstruksi konsep matematika. Freudenthal mengenalkan istilah "guided reinvention" sebagai proses yang dilakukan siswa secara aktif untuk menemukan kembali suatu konsep 
matematika dengan bimbingan guru. Kebermaknaan konsep matematika merupakan konsep utama dari RME.

Beberapa karakteristik dan prinsip Realistic Mathematics Education (RME), maka langkahlangkah pembelajaran yang dilaksanakan dalam pengembangan ini adalah sebagai berikut.

1) Memahami masalah kontekstual

Pada langkah ini guru menyajikan masalah kontekstual kepada siswa. Selanjutnya guru meminta siswa untuk memahami masalah itu terlebih dahulu. Karakteristik Realistic Mathematics Education (RME) yang muncul pada langkah ini adalah menggunakan konteks.

2) Menjelaskan masalah kontekstual

Langkah ini ditempuh saat siswa mengalami kesulitan memahami masalah kontekstual. Pada langkah ini guru memberikan bantuan dengan memberi petunjuk atau pertanyaan seperlunya yang dapat mengarahkan siswa untuk memahami masalah.

3) Menyelesaikan masalah kontekstual

Pada tahap ini siswa didorong menyelesaikan masalah kontekstual secara individual berdasar kemampuannya dengan memanfaatkan petunjuk-petunjuk yang telah disediakan. Siswa mempunyai kebebasan menggunakan caranya sendiri. Dalam proses memecahkan masalah, sesungguhnya siswa dipancing atau diarahkan untuk berfikir menemukan atau mengkonstruksi pengetahuan untuk dirinya.

4) Membandingkan dan mendiskusikan jawaban

Pada tahap ini guru pada awalnya meminta siswa untuk membandingkan dan mendiskusikan jawaban dengan pasangannya. Diskusi ini adalah wahana bagi sepasang siswa mendiskusikan jawaban masing-masing. Dari diskusi ini diharapkan muncul jawaban yang dapat disepakati oleh kedua siswa. Selanjutnya guru meminta siswa untuk membandingkan dan mendiskusikan jawaban yang dimilikinya dalam diskusi kelas. Pada tahap ini guru menunjuk atau memberikan kesempatan kepada pasangan siswa untuk mengemukakan jawaban yang dimilikinya ke muka kelas dan mendorong siswa yang lain untuk mencermati dan menanggapi jawaban yang muncul di muka kelas.

5) Menyimpulkan

Dari hasil diskusi kelas guru mengarahkan siswa untuk menarik kesimpulan mengenai pemecahan masalah, konsep, prosedur atau prinsip yang telah dibangun bersama. Pada tahap ini karakteristik Realistic Mathematics Education (RME) yang muncul adalah interaktif serta menggunakan kontribusi siswa.

\section{Keunggulan Komik sebagai Media Pembelajaran RME}

Komik merupakan suatu bentuk media komunikasi visual yang mempunyai kekuatan untuk menyampaikan informasi secara popular dan mudah dimengerti. Hal ini dikarenakan komik memadukan kekuatan gambar dan tulisan, yang dirangkai dalam satu alur cerita sehingga membuat informasi mudah diserap.

Teks membuatnya mudah dimengerti dan alur membuatnya lebih mudah diikuti dan diingat. Komik juga merupakan media komunikasi visual dan lebih dari sekedar cerita yang ringan dan menghibur. Sebagai media komunikasi visual, komik dapat diterapkan sebagai alat bantu pendidikan dan mampu menyampaikan informasi secara efektif dan efisien.

Dengan demikian suatu permasalahan matematika dalam kehidupan sehari-hari yang disajikan dengan kata-kata yang sering kali dianggap sulit bagi siswa, ketika disajikan dengan media komik yang memadukan kekuatan gambar dan tulisan menjadikan permasalahan dapat mudah diserap dan diikuti siswa. Sebagai media komunikasi visual, komik dapat menyajikan permasalahan secara efektif dan efisien sehingga dengan penggunaan komik akan mendukung tercapainya tujuan pembelajaran. 


\section{Buku Teks-Mini Berbasis CIRC}

Buku teks-mini berbasis CIRC (Cooperative Integrated Reading and Composition) adalah buku teks-mini berbasis CIRC yang penggunaan waktu menjadi lebih efektif. Siswa dikondisikan dalam tim-tim kooperatif yang kemudian dikoordinasikan dengan pengajaran kelompok membaca, supaya memenuhi tujuan lain seperti pemahaman membaca, kosa kata, pembacaan pesan, dan ejaan. Buku teks-mini juga memuat tampilan warna full colour, gambar yang bervariasi, dan berbagai soal-soal latihan seperti: UN, OSN, dan UAS, pemgilustrasian rumus-rumus materi serta dicetak dalam bentuk spiral.

\section{METODE}

Komik matematika berbasis RME (Realistic Mathematics Education) materi keliling dan luas segitiga kelas VII ini dikembangkan dengan model pengembangan 4-D yang diadaptasi dari Thiagarajan, Semmel dan Semmel. Model pengembangan ini terdiri dari 4 tahapan yaitu define, design, develop, dan disemminate.

Jenis data dalam pengembangan ini terdiri atas dua macam yaitu data kualitatif yakni data yang diperoleh dari: (a) pilihan jawaban dari responden yang berupa sangat setuju, setuju, kurang sutuju, tidak setuju, (b) data yang diperoleh dari penarikan kesimpulan setelah melakukan analisis data, yaitu berupa valid atau tidak valid, (c) data yang dikumpulkan dari komentar dan saran pada lembar validasi, serta data kuantitatif yakni skor penilaian yang ditulis pada angket validasi mengenai penilaian terhadap komik matematika yang dikembangkan. Teknik analisis data disesuaikan dengan data yang ada. Data kuantitatif diperoleh dari perhitungan skor pada angket, sedangkan data kualitatif berupa komentar dan saran yang langsung ditulis oleh ahli media, ahli materi dan ahli praktisi dilembar validasi komentar dan saran yang berupa evaluasi kebenaran media, bagian yang salah, dan saran perbaikan komik matematika yang diisi oleh validator ahli, praktisi dan user.

Lokasi yang digunakan dalam penelitian ini yaitu SMP Wahid Hasyim Malang, pengembangan ini melibatkan 1 guru dari sekolah tersebut. Validator user dalam pengembangan ini yaitu 9 siswa kelas VII SMP Wahid Hasyim Malang. Adapun prosedur pengembangan komik matematika dalam pengembangan ini dapat dilihat pada bagan berikut. 


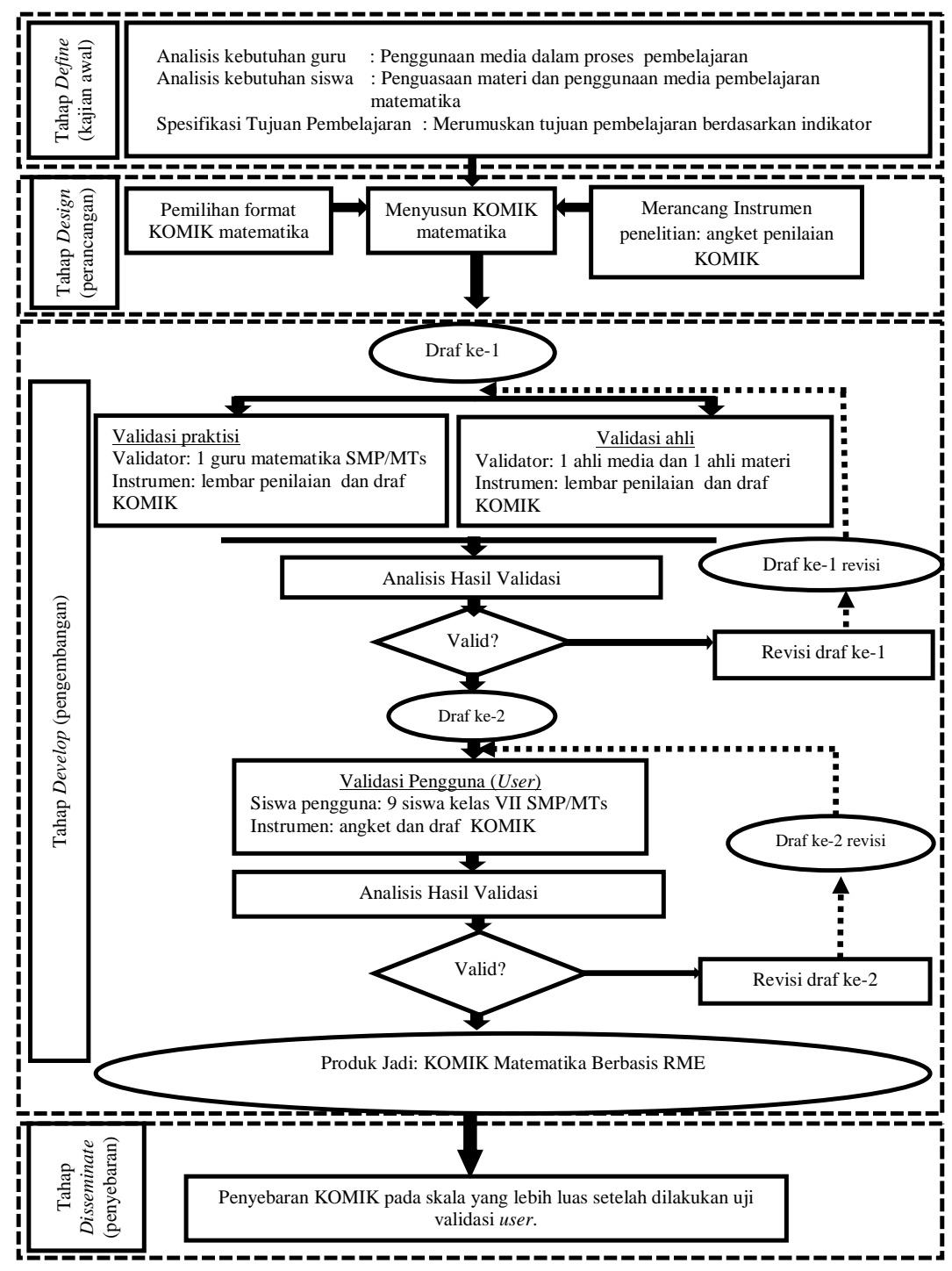

\section{Bagan 1 Model Pengembangan 4-D diadaptasi dari Thiagarajan, Semmel, dan Semmel (dalam Trianto, 2007: 63)}

\section{HASIL}

\section{Pengembangan Produk}

Hasil dari pengembangan ini berupa komik matematika berbasis RME (Realistic Mathematics Education) untuk meningkatkan kemampuan pemecahan masalah keliling dan luas segitiga siswa SMP. komik ini ditampilkan dengan layout yang menarik dan dicetak dengan menggunakan kertas HVS 100 gram berukuran A5 (14,8 cm x $21 \mathrm{~cm})$ sedangkan untuk bagian cover dicetak menggunakan kertas ivory 260 yang dijilid dalam bentuk soft cover tanpa laminasi. Untuk mengembangkan komik ini digunakan program aplikasi komputer, yaitu coreldraw X7 dan photoshop CS3.

Tahap pengembangan yang dilakukan adalah yang pertama tahap define meliputi analisis kebutuhan guru, analisis kebutuhan siswa, dan analisis tujuan pembelajaran. Kemudian yang kedua adalah tahap design, yaitu pemilihan format komik matematika, menyusun komik matematika, merancang instrumen penelitian. Yang ketiga yaitu tahap develop, dilakukan uji validasi draf awal komik kepada validator ahli, praktisi dan user. Sedangkan tahap disemminate belum terlaksana karena keterbatasan waktu dan biaya.

Berikut tampilan bagian-bagian komik matematika 


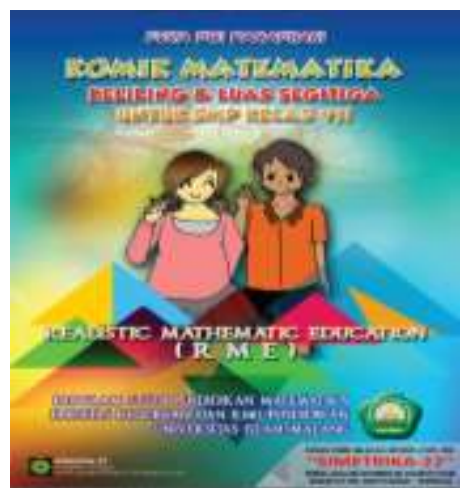

Gambar 1. Tampilan Cover Komik

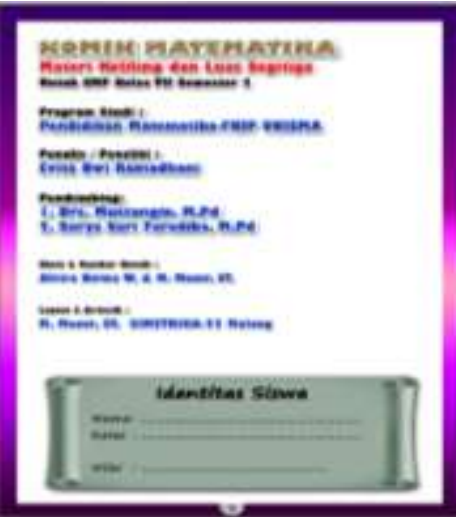

Gambar 2. Halaman Identitas Komik

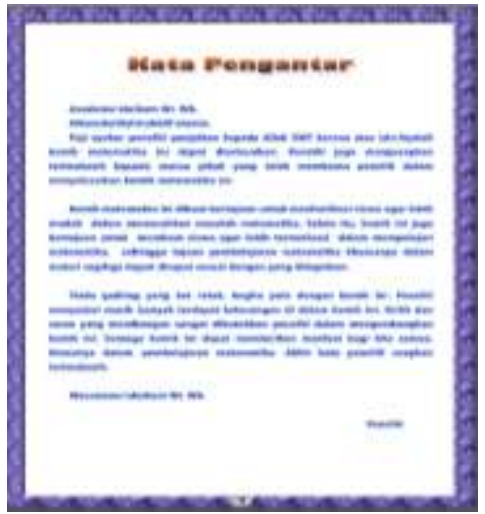

Gambar 3. Kata Pengantar

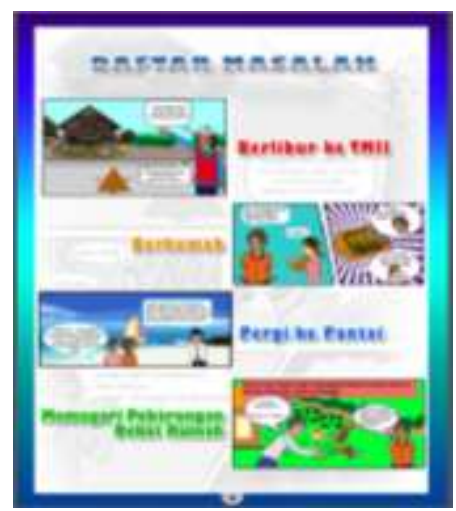

Gambar 4 Daftar Masalah Komik 


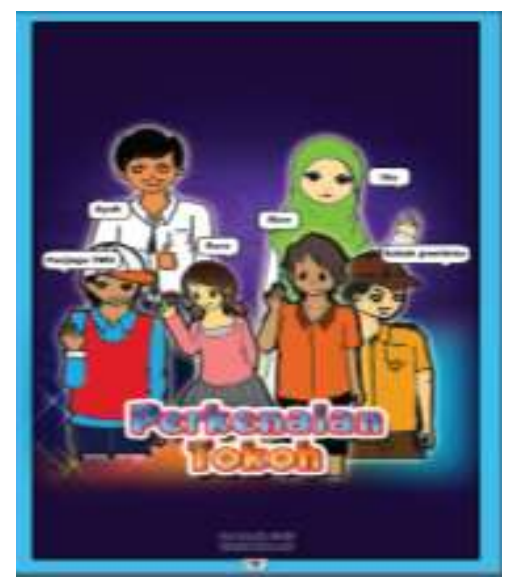

\section{Gambar 5 Pengenalan Tokoh Komik}

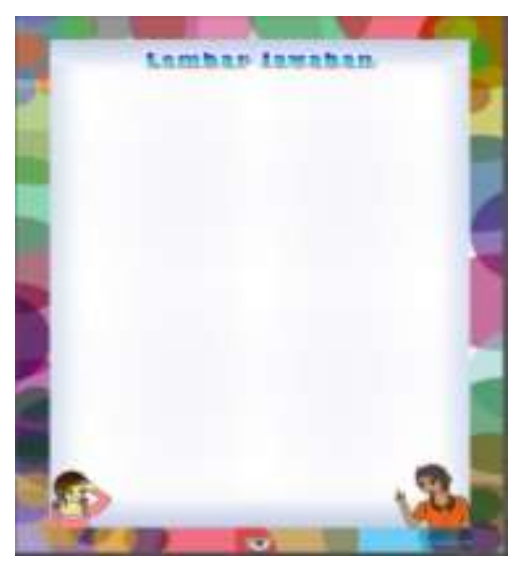

Gambar 6 Lembar Jawaban

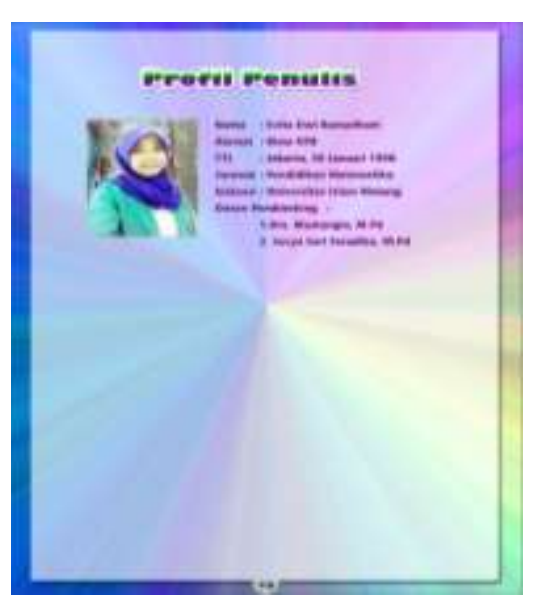

Gambar 7 Profil Penulis

\section{Telaan Ahli}

Pada validasi komik, ada empat validator yaitu tiga validator ahli meliputi ahli materi dan ahli media, praktisi, dan user. Berikut adalah hasil validasi ahli, praktisi, dan user. 
Tabel 1 : Analisis Data Validasi oleh Ahli Media

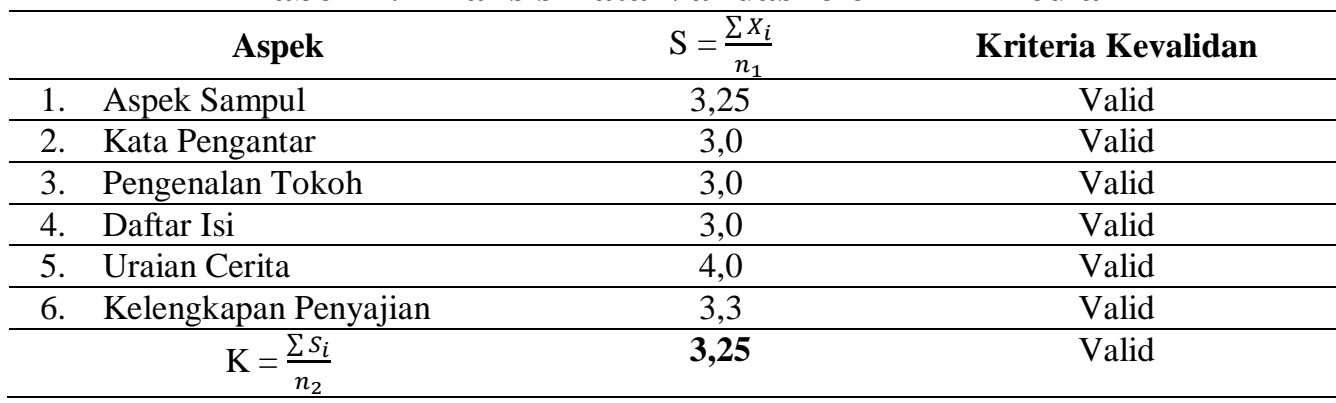

Tabel 2 Analisis Data Validasi oleh Ahli Materi

\begin{tabular}{lccc}
\hline \multicolumn{1}{c}{ Aspek } & $\mathrm{S}=\frac{\sum x_{i}}{n_{1}}$ & Kriteria Kevalidan \\
\hline 1. & Aspek kelayakan isi & 3,25 & Valid \\
\hline 2. Aktifitas Pemecahan Masalah & 3,0 & Valid \\
\hline 3. Aspek Penyajian Komik & 3,0 & Valid \\
\hline 4. Aspek Kebahasaan & 3,0 & Valid \\
\hline 5. Aspek Kegrafisan & 3,0 & \\
\hline & $\mathrm{K}=\frac{\sum S_{i}}{n_{2}}$ & $\mathbf{3 , 0 5}$ & Valid \\
\hline
\end{tabular}

Tabel 3 Analisis Data Validasi oleh Praktisi

\begin{tabular}{clcc}
\hline \multicolumn{1}{c}{ Aspek } & $\mathrm{S}=\frac{\sum X_{i}}{n_{1}}$ & Kriteria Kevalidan \\
\hline 1. & Aspek Kelayakan Isi & 4,0 & Valid \\
\hline 2. & Aspek Pemecahan Masalah & 3,4 & Valid \\
\hline 3. & Aspek Penyajian Komik & 3,3 & Valid \\
\hline 4. & Aspek Kebahasaan & 3,4 & Valid \\
\hline 5. & Aspek Kegrafisan & 3,4 & Valid \\
\hline & $\mathrm{K}=\frac{\sum s_{i}}{n_{2}}$ & $\mathbf{3 , 5}$ & \\
\hline
\end{tabular}

Tabel 4 Analisis Data Kelompok Validasi User

\begin{tabular}{|c|c|c|c|}
\hline No. & Kelompok Uji Pengguna & $\mathbf{K}$ & Keterangan \\
\hline 1. & Uji pengguna siswa berkemampuan matematika baik & $\mathbf{3 , 3 3}$ & Valid \\
\hline 2. & Uji pengguna siswa berkemampuan matematika sedang & 3,44 & Valid \\
\hline \multirow[t]{2}{*}{3.} & Uji pengguna siswa berkemampuan matematika kurang & $\mathbf{3 , 5 6}$ & Valid \\
\hline & $\sum K_{i}$ & 10,33 & \\
\hline & Rata-rata total $=\frac{\sum K_{i}}{N}$ & 3,44 & Valid \\
\hline
\end{tabular}

Berdasarkan penilaian para ahli nilai kevalidan 3,25 oleh ahli media, 3,05 oleh ahli materi, dan 3,5 oleh praktisi. Sedangkan menurut user, e-book dinyatakan valid dengan nilai kevalidan 3,44. Berdasarkan hasil validasi tersebut dapat disimpulkan bahwa komik matematika berbasis RME (Realistic Mathematics Education) untuk meningkatkan kemampuan pemecahan masalah keliling dan luas segitiga siswa SMP kelas VII.

\section{TANGGAPAN SISWA}

Dari hasil validasi user diperoleh kritik serta komentar dari siswa diantaranya sebagai berikut. (1) Pembelajaran menggunakan komik matematika sangat menyenangkan; (2) Komik matematika ini membuat siswa untuk lebih giat belajar dengan tampilan yang menarik dan soal 
latihan dikerjakan secara berkelompok sehingga bisa mudah untuk menyelesaikannya; (3) Komik matematika ini membuat rasa semangat saya dalam belajar semakin tinggi. Saya harap semua orang dapat melakukan pembelajaran dengan komik berbasis RME; (4) Menyenangkan karena kita dapat mudah memahami dan tidak bosan.

\section{REVISI PRODUK}

Setelah memperoleh data kualitatif berdasarkan komentar dan saran dari masing-masing validator, selanjutnya dilakukan perbaikan sesuai dengan komentar dan saran dari validator agar produk yang dikembangkan menjadi semakin baik dan mendekati sempurna. Beberapa revisi yang dilakukan adalah sebagai berikut: memperbaiki kesalahan penulisan pada judul cover, memperjelas gambar pada daftar masalah, kesalahan penulisan.

\section{PEMBAHASAN}

Menurut Setyosari (2013:223),”pengembangan adalah suatu proses yang dipakai untuk mengembangkan dan memvalidasi produk pendidikan. Dalam pengembangan ini, produk yang dikembangkan adalah komik matematika berbasis RME (Realistic Mathematics Education) untuk meningkatkan kemampuan pemecahan masalah keliling dan luas segitiga siswa SMP kelas VII. Pengembangan komik matematika menggunakan tahapan-tahapan model pengembangan 4D (fourD) seperti yang disarankan oleh Thigarajan, dkk (dalam Trianto, 2007:65). Model ini terdiri dari 4 tahapan yaitu define, design, develop, dan disemminate.

Komik ini telah divalidasi oleh validator media, validator materi, validator praktisi, dan validator user. Berdasarkan penilaian para ahli nilai kevalidan 3,25 oleh ahli media, 3,05 oleh ahli materi, dan 3,5 oleh praktisi. Sedangkan menurut user, komik matematika dinyatakan valid dengan nilai kevalidan 3,44. Berdasarkan hasil validasi tersebut dapat disimpulkan bahwa komik matematika berbasis RME (Realistic Mathematics Education) untuk meningkatkan kemampuan pemecahan masalah keliling dan luas segitiga siswa SMP kelas VII valid dan dapat digunakan sebagai media dalam pembelajaran materi segitiga.

\section{SIMPULAN DAN SARAN}

Dalam penggunaan media komik matematika ini hendaknya digunakan sebagai referensi untuk menunjang pembelajaran siswa SMP/MTs kelas VII khususnya materi segitiga. Selain itu, sebelum menggunakan komik matematika ini, sebaiknya pengguna (user) yaitu guru dan siswa sudah mempelajari terlebih dahulu materi segitiga dan tentang basis yang digunakan, agar dapat mengikuti langkah-langkah pembelajaran berdasarkan pendekatan RME.

\section{DAFTAR RUJUKAN}

Arsyad, Azhar.2011. Media Pembelajaran. Bandung: PT. Remaja Rosda Karya.

Setyosari, Punaji. 2013. Metode Penelitian Pendidikan dan Pengembangan. Jakarta : Kencana Prenadamedia Group.

Sudjana, Nana dan Riva'i, Ahmad. 2015. Media Pengajaran. Jakarta: Sinar Baru Algensindo. Trianto. 2007. Mendesain Model Pembelajaran Inovatif-Progresif. Jakarta: Prestasi Pustaka Wijaya, Ariyadi. 2012. Pendidikan Matematika Realistik. Yogyakarta: Graha Ilmu. 